\title{
PENGARUH MODEL LEARNING CYCLE BERBASIS MEDIA AUDIO VISUAL TERHADAP KEMAMPUAN MENULIS PUISI SISWA SMA
}

\author{
Liondes Launjara, Dian Nuzulia Armariena, Masnunah \\ Universitas PGRI Palembang \\ Email: liondeslaunjara06@gmail.com,diannuzulia@univpgri-palembang.ac.id, \\ masnunah42@gmail.com
}

\begin{abstract}
Abstrak: Penelitian ini bertujuan untuk menguji signifikansi pengaruh model pembelajaran learning cycle berbasis media audio visual terhadap kemampuan menulis puisi siswa SMA kelas X. Penelitian dilakukan dengan pedekatan eksperimen. Yang menjadi sampel penelitian adalah kelas X IIS 1 sebagai kelas eksperimen dan kelas X IIS 2 sebagai kelas kontrol. Teknik pengumpulan data menggunakan tes menulis puisi. Teknik analisis data menggunakan rumus uji-t dengan bantuan SPSS versi 21. Berdasarkan hasil penelitian dapat ditarik kesimpulan bahwa (1) rata-rata hasil tes siswa kelompok eksperimen yang dapat perlakuan model pembelajaran learning cycle berbasis media audio visual terhadap kemampuan menulis puisi lebih besar dibandingkan dengan rata-rata hasil tes siswa kelompok kontrol dengan menggunakan model pembelajaran konvensional dan (2) terdapat pengaruh model pembelajaran learning cycle berbasis media audio visual terhadap kemampuan menulis puisi siswa kelas $\mathrm{X}$ yang ditunjukkan dengan koefisien thitung sebesar 2,34 atau lebih besar dari koefisien tabel sebesar 1,669. Dengan demikian, tes hasil belajar siswa yang menggunakan model pembelajaran learning cycle berbasis media audio visual lebih baik hasilnya daripada tes hasil belajar menggunakan model pembelajaran biasa.
\end{abstract}

Kata Kunci: model learning cycle, media audio visual, kemampuan menulis puisi.

\section{THE EFFECT OF A CYCLE LEARNING MODEL BASED ON AUDIO VISUAL MEDIA ON THE ABILITY OF WRITING THE POETRY IN SENIOR HIGH SCHOOL}

\begin{abstract}
This study aims to test the significance of the effect of the learning cycle learning model based on audio-visual media on the ability to write poetry of class 10 high school students. The research sample is class X IIS 1 as the experimental class and class X IIS 2 as the control class. The data collection technique used a poetry writing test. The data analysis technique used the t-test formula with the help of SPSS version 21. Based on the results of the study, it can be concluded that (1) the average test results of the experimental group students who were treated with the learning cycle learning model based on audio-visual media on the ability to write poetry were greater than with the average test results of the control group students using conventional learning models and (2) there is an effect of the learning cycle learning model based on audio-visual media on the ability to write poetry of class $X$ students as indicated by the tcount coefficient of 2.34 or greater than the t-table coefficient. amounting to 1.669. Thus, the results of student learning tests using the learning cycle model based on audio-visual media have better results than the learning outcomes test using the ordinary learning model.
\end{abstract}

Keywords: learning cycle model, audio visual media, writing poetry ability.

BASASTRA Jurnal Bahasa, Sastra, dan Pengajarannya

Volume 9 Nomor 1, April 2021, P-ISSN 2302-6405, E-ISSN 2714-9765 


\section{PENDAHULUAN}

Pendidikan merupakan suatu proses atau cara yang dilakukan secara sadar serta terencana oleh guru dengan siswa untuk mewujudkan suasana belajar dan proses pembelajaran yang bertujuan untuk mengetahui penguasaan kemampuan siswa melalui hasil belajar yang diinginkan. Pembelajaran merupakan suatu proses mendidik yang dilakukan oleh guru dan sebuah proses belajar yang dilakukan oleh siswa yang bertujuan untuk membentuk tingkah laku siswa dan meningkatkan kemampuan siswa sebagai hasil pembelajaran.

Untuk mengetahui hasil belajar siswa, perlu diadakan evaluasi dalam pembelajaran. Evaluasi merupakan sebuah cara yang dilakukan oleh guru untuk melihat berhasil atau tidaknya proses pembelajaran yang dilakukan. Pelaksanaan evaluasi ini biasanya dilakukan di akhir pembelajaran.

Berdasarkan silabus materi pembelajaran Bahasa Indonesia, yang harus dikuasai siswa pada jenjang Sekolah Menengah Atas (SMA) khususnya untuk kelas $\mathrm{X}$ adalah menyusun laporan hasil observasi, mengembangkan pendapat dalam eksposisi, menyampaikan ide melalui anekdot, melestarikan nilai kearifan lokal melalui cerita rakyat, membuat kesepakatan melalui negosiasi, berpendapat melalui debat, belajar dari biografi, mendalami puisi. Kompetensi dasar yang diharapkan adalah siswa mampu mengidentifikasi komponen penting dalam puisi, mendemontrasikan puisi, menganalisis unsur pembangun puisi, menulis puisi. Apabila siswa mampu menguasai materi pembelajaran sesuai dengan kompetensi dasar yang diharapkan pada pembelajaran berbasis teks, maka siswa dapat menerapkan dan mengembangkan pengetahuannya untuk memecahkan permasalahan secara efektif dan kreatif. Tuntutan dari kurikulum 2013 dalam pembelajaran ini adalah siswa lebih berperan aktif dibandingkan guru, guru hanya mengarahkan dan mengawasi aktivitas yang dilakukan oleh siswa dalam pembelajaran dan siswalah yang menggali informasi secara penuh tentang materi yang diajarkan.

Menulis puisi sangat berkaitan dengan keterampilan menulis. Dalam proses menulis puisi, siswa cenderung kesulitan untuk menuangkan pengalaman atau ide-idenya ke dalam bentuk media tulis. Salah satu cara untuk mengatasi permasalahan yang dihadapi siswa pada saat melakukan pembelajaran menulis puisi adalah menggunakan model pembelajaran learning cycle, yang bertujuan untuk membantu siswa dalam berpikir kreatif dan tidak hanya terpaku dengan struktur puisinya saja, tetapi juga dibantu dengan pengalaman untuk menuangkan ide si penulis dengan menggunakan model pembelajaran.

Berdasarkan observasi awal peneliti memilih ke SMA Negeri 1 Lubai untuk dijadikan objek penelitian karena peneliti sudah mewawancarai guru Bahasa Indonesia bahwa SMA 
Negeri 1 Lubai sudah menerapkan pembelajaran berdasarkan materi dalam Silabus Bahasa Indonesia tetapi siswa masih cenderung bersifat pasif dan terkait dengan pembelajaran menulis puisi, siswa masih sulit dalam hal menulis, karena ada beberapa faktor yang memengaruhi yaitu siswa tidak mampu untuk merangkai kalimat per kalimat ke dalam bentuk tulisan, siswa tidak suka dalam pembelajaran menulis puisi, siswa lebih suka pembelajaran pengalaman pribadi, karena pembelajaran menulis pengalaman pribadi ini sangat berhubungan dengan kehidupan sehari-hari, seperti pengalaman yang pernah dialami ketika berlibur dengan orang tuanya. Siswa belum terampil dalam menulis puisi disebabkan kurangnya minat siswa dalam pembelajaran menulis puisi, kurangnya kemampuan siswa dalam merangkai kata-kata dalam menulis puisi, karena siswa susah dalam menentukan kata-kat yang akan ditulis dan siswa lebih suka melihat punya teman, ada sebagian anak yang suka belajar suka sastra dan ada yang tidak suka, hal ini dikarenakan penerapan yang diberikan oleh guru Bahasa Indonesia dalam pembelajaran menulis puisi siswa kelas X SMA Negeri 1 Lubai masih menggunakan model pembelajaran konvensional. Model pembelajaran konvensional yang dimaksud adalah pembelajaran presentasi atau ceramah dan penugasan melalui pengerjaan soal-soal menyebabkan proses belajar tidak menarik dan siswa cepat bosan.
Untuk mengatasi hal tersebut peneliti akan menerapkan model pembelajaran learning cycle berbasis media audio visual dalam menjelaskan materi pembelajaran menulis puisi untuk menghasilkan suasana belajar yang bervariasi, agar siswa termotivasi mengikuti kegiatan pembelajaran.

Model pembelajaran learning cycle adalah suatu model pembelajaran yang berpusat pada pembelajar (student centered), LC merupakan rangkaian tahap-tahap kegiatan (fase) yang diorganisasi sedemikian rupa sehingga pembelajar dapat menguasai kompetensi-kompetensi yang harus dicapai dalam pembelajaran dengan jalan berperan aktif (Ngalimun 2017: 247). Model pembelajaran ini selain menyediakan tahap-tahap yang terstruktur untuk membantu siswa dalam proses belajar, juga memberikan sumber ide-ide yang didapat dari sebuah pengalaman yang bisa dituangkan kedalam sebuah puisi yang ditulis. Media pembelajaran audio visual merupakan suatu media yang dapat menampilkan unsur gambar dan suara secara bersamaan pada saat mengomunikasikan pesan atau informasi, dan juga. Media audio visual dapat mengungkapkan suatu objek dan peristiwa seperti keadaan yang sesungguhnya, dan perangkat yang digunakan dalam audio visual ini adalah mesin proyektor, tape recorder, dan proyektor visual yang lebar. Audio visual merupakan salah satu media yang menampilkan unsur suara dan unsur gambar. Penggabungan kedua 
unsur inilah yang membuat media audio visual memiliki kemampuan yang lebih baik.

\section{METODE}

Sugiyono (2017: 6) menjelaskan bahwa metode penelitian adalah suatu cara ilmiah untuk mendapatkan data atau tujuan dan kegunaan tertentu. Sehubungan dengan masalah yang akan diteliti, metode yang digunakan dalam peneliti ini adalah metode eksperimen. Metode eksperimen adalah suatu metode penelitian yang digunakan untuk mencari pengaruh terhadap yang lain dalam kondisi terkendali. Sukardi (2011: 179) berpendapat metode penelitian eksperimen adalah metode yang sistematis guna membangun hubungan yang mengandung fenomena sebab akibat. Berdasarkan pendapat tersebut maka metode yang digunakan dalam penelitian ini adalah metode eksperimen yaitu suatu metode yang terdapat dua kelompok kelas terdiri dari kelas eksperimen dan kelas kontrol yang dipilih secara random.

Pengumpulan data merupakan cara untuk memperoleh data atau informasi yang diperlukan dalam penelitian (Arikunto, 2006: 272). Di dalam penelitian ini peneliti mengumpulkan data melalui kegiatan observasi, wawancara, dan tes.

Sebelum peneliti melakukan analisis data, maka peneliti terlebih dahulu membuat suatu instrumen berbentuk tes. Instrumen yang digunakan peneliti dalam penelitian ini yaitu instrumen teks. Intrumen yang berupa teks digunakan peneliti untuk mengetahui pengaruh model pembelajaran learning cycle terhadap kemampuan siswa khususnya kelas $\mathrm{X}$ dalam hal menulis puisi dan untuk mengetahui hasil belajar siswa yang diperoleh setelah mengikuti kegiatan pembelajaran di kelas. Bentuk tes kemampuan menulis puisi yaitu siswa diberi suatu masalah atau tema puisi kemudian siswa mengembangkan tema tersebut menjadi sebuah puisi yang sesuai dengan unsur-unsur puisi.

Pemberian nilai untuk soal tersebut disesuaikan dengan ketepatan siswa dalam menulis puisi yang sesuai dengan unsur-unsur puisi. Untuk menilai suatu puisi yang telah di buat siswa, terlebih dahulu ditentukan aspek atau komponen pokok yang akan di nilai dalam tulisan puisi tersebut. Penskoran tersebut menggunakan skala nilai 1-100. Penentuan aspek atau komponen pokok yang dinilai dan penskoranya disesuaikan dengan unsur-unsur puisi yang ada.

\section{HASIL DAN PEMBAHASAN}

Berdasarkan data penelitian yang didapat sebelumnya diketahui bahwa skor yang diperoleh siswa kelompok kontrol dalam tes awal menulis puisi, jumlah sampel $(\mathrm{N})$, rerata (mean), nilai terendah (minimum), nilai tertinggi (maximum), jumlah nilai keselurhan (sum). 
Tabel 1. Deskripsi Statistik

\begin{tabular}{llr}
\hline & \multicolumn{2}{c}{ Kontrol } \\
\hline $\mathrm{N}$ & Valid & 36 \\
\cline { 2 - 3 } \multicolumn{1}{c}{ Missing } & 0 \\
\hline Mean & 71.72 \\
Median & 62.5 \\
Minimum & 93 \\
Maximum & 62 \\
Sum & 2582 \\
\hline
\end{tabular}

Pada tabel (1) diketahui bahwa jumlah sampel untuk kelompok kontrol sebanyak 36 orang, rerata (mean) yang didapat sebesaar 71,72 , nilai terendah (minimum) adalah 62,5 dan nilai tertinggi (maksimum) adalah 93 dan jumlah keseluruhan (sum) adalah 2582.

Tabel 2. Nilai Kontrol

\begin{tabular}{lrrr}
\hline & Observed N & Expected N & Residual \\
\hline 63 & 6 & 4.6 & -2.6 \\
69 & 15 & 4.6 & -2.6 \\
75 & 8 & 4.6 & 7.4 \\
81 & 3 & 4.6 & 3.4 \\
87 & 3 & 4.6 & -1.6 \\
93 & 1 & 4.6 & -2.6 \\
\hline Total & $\mathbf{3 6}$ & & \\
\hline
\end{tabular}

Pada tabel (2) di atas merupakan deskripsi statistik dari tes nilai awal kelompok kontrol. Dari tabel ini dapat diketahui bahwa jumlah siswa kelompok kontrol sebanyak 36 siswa. Dari tabel itu juga dapat diketahui 6 sel skor/nilai (100\%) yang didapat dari hasil tes awal membaca pemahaman siswa, diperoleh frekuensi nilai harapan yang muncul kurang dari 5 . minimal rekuensi harapan (expected frequencies) yang mucul pada masingmasing skor/nilai yang timbul adalah sebanyak 4,6.

Dari tabel (2) diketahui bahwa frekuensi observasi yang mucul dari 32 siswa sampel pada kelompok kontrol adalah 2 orang mendapat nilai $63 ; 6$ orang mendapat nilai $69 ; 15$ orang mendapat nilai $75 ; 8$ orang mendapat nilai $81 ; 3$ orang mendapat nilai $87 ; 3$ orang mendapat nilai $93 ; 1$.

Tabel 3. Tes Statistik

\begin{tabular}{lr}
\hline \multicolumn{2}{c}{ Test Statistics } \\
\hline \multicolumn{2}{c}{ Pretest Kontrol } \\
\hline Chi-Square & $12.211^{\mathrm{a}}$ \\
df & 5 \\
Asymp. Sig. & .002 \\
\hline a. 7 cells (100.0\%) have expected frequencies less than \\
5. The minimum expected cell frequency is 4.6. \\
\hline
\end{tabular}

Tabel (3) adalah tes statistik melalui tabel ini dapat diketahui bahwa pada kelompok kontrol tes statistik Chi-Square $_{\text {hitung }}=19.432$ dengan derajat bebas $=\mathrm{n}-1=5)$, dan probabilitas (Asymptotic. Sig $)=0.002$.

Tabel 4. Keterangan Hasil

\begin{tabular}{|c|c|c|c|c|}
\hline Kelompok & $\begin{array}{l}\text { Chi- } \\
\text { Square } \\
\text { hitung }\end{array}$ & $\begin{array}{l}\text { Chi- } \\
\text { Square } \\
\text { tabel }\end{array}$ & & tatus \\
\hline Kontro & 11.32 & (df5) & $\mathrm{X}^{2}-$ & Data \\
\hline \multirow[t]{6}{*}{1} & 2 & 21.31 & hitung & berdistribus \\
\hline & & 1 & $<X^{2}-$ & i normal \\
\hline & & & tabel & dan \\
\hline & & & $\rightarrow$ Ho & homogen \\
\hline & & & diterim & \\
\hline & & & $\mathrm{a}$ & \\
\hline
\end{tabular}
chi-square $_{\text {tabel }}$ (chi kuadrat hitung $_{\text {- chi }}$ kuadrat $_{\text {tabel}}$ ), maka Ho diterima. Artinya, data sampel tes awal kelompok kontrol berdistribusi normal dan homogen. Untuk perhitungan uji normalitas dapat dilakukan dengan menggunakan teknik P-P Plot. 


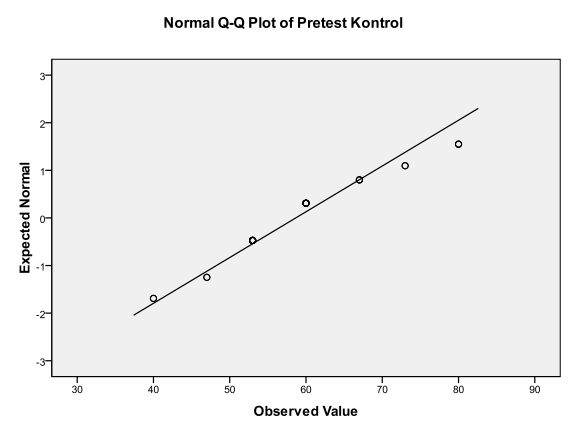

Grafik 1. P-P Plot untuk Nilai Tes Kelas Kontrol

Grafik di atas menunjukkan bahwa titik-titik data menyebar di sekitar garis diagonal, maka sebaran distribusi data dinyatakan normal. Dengan demikian, dapat dikatakan bahwa sampel pada tes kelompok kontrol berdistribusi normal dan homogen.

\section{Uji Normalitas dan Homogenitas Sempel Kelompok Eksperimen}

Berdasarkan data penelitian yang didapat sebelumnya diketahui bahwa skor yang diperoleh siswa kelompok kontrol dalam tes, jumlah sampel $(\mathrm{N})$, rerata (mean), nilai terendah (minimum), nilai tertinggi (maximum) dan jumlah seluruh nilai (sum).

Tabel 5. Deskripsi Statistik

\begin{tabular}{lrr}
\hline & \multicolumn{2}{c}{ Eksperimen } \\
\hline $\mathrm{N} \quad$ Valid & 35 \\
\cline { 2 - 3 } \multicolumn{1}{c}{ Missing } & 0 \\
\hline Mean & 87 \\
Median & 67.00 \\
Minimum & 75 \\
Maximum & 100 \\
Sum & 3051 \\
\hline
\end{tabular}

Pada tabel (5) diketahui bahwa

jumlah sampel untuk kelompok eksperimen sebanyak 35 orang, rerata (mean) yang didapat sebesaar 87, nilai terendah (minimum) adalah 75 dan nilai tertinggi (maksimum) adalah 100 dan nilai keseluruhan (sum) adalah 3051.

Tabel 6. Nilai Tes Eksperimen

\begin{tabular}{cccc}
\hline \multicolumn{4}{c}{ Eksperimen } \\
\hline \multicolumn{4}{c}{ Observed } \\
N & Expected N & Residual \\
\hline 75 & 3 & 4.6 & -1.6 \\
80 & 10 & 4.6 & 5.4 \\
85 & 7 & 4.6 & 2.4 \\
90 & 4 & 4.6 & -.6 \\
95 & 5 & 4.6 & -1.6 \\
100 & 3 & 4.6 & -1.6 \\
\hline Total & 35 & & \\
\hline
\end{tabular}

Pada tabel (6) di atas merupakan deskripsi statistik dari tes nilai kelompok eksperimen. Dari tabel ini dapat diketahui bahwa jumlah siswa kelompok kontrol sebanyak 35 siswa. Dari tabel itu juga dapat diketahui 7 sel skor/nilai (100\%) yang didapat dari hasil tes awal membaca pemahaman siswa, diperoleh frekuensi nilai harapan yang muncul kurang dari 5. minimal frekuensi harapan (expected frequencies) yang mucul pada masingmasing skor/nilai yang timbul adalah sebanyak 4.6.

Dari tabel (6) diketahui bahwa frekuensi observasi yang mucul dari 35 siswa sampel pada kelompok eksperimen untuk tes awal adalah 4 orang mendapat nilai $75 ; 4$ orang mendapat nilai $80 ; 0$ orang mendapat nilai $85 ; 12$ orang mendapat nilai $90 ; 15$ orang mendapat nilai $100 ; 6$ orang. 
Tabel 7. Tes Statistik

\begin{tabular}{lr}
\hline \multicolumn{2}{c}{ Test Statistics } \\
\hline \multicolumn{2}{c}{ Eksperimen } \\
\hline Chi- & $9.311^{\mathrm{a}}$ \\
Square & 6 \\
df & .041 \\
Asymp. & \\
Sig. & \\
\hline a. 7 cells (100.0\%) have expected \\
frequencies less than 5. The minimum \\
expected cell frequency is 4.6.
\end{tabular}

Tabel (7) adalah tes statistik melalui tabel ini dapat diketahui bahwa pada kelompok kontrol tes statistik Chi-Square hitung $_{\text {- }}$ 9,311 dengan derajat bebas $=\mathrm{n}-1=5$ ), dan probabilitas $($ Asymptotic. Sig $)=0.041$.

Tabel 8. Keterangan Hasil

\begin{tabular}{cccll}
\hline Kelompok & $\begin{array}{c}\text { Chi- } \\
\text { Squar } \\
\text { e } \\
\text { hitung }\end{array}$ & $\begin{array}{c}\text { Chi- } \\
\text { Square } \\
\text { tabel }\end{array}$ & & \\
\hline eksperi & 9.3 & (df5) & $\mathrm{X}^{2}-$ & Data \\
men & 11 & 22.3 & hitun & berdistri \\
& & 22 & $\mathrm{~g}<$ & busi \\
& & & $\mathrm{X}^{2}-$ & normal \\
& & & tabel & dan \\
& & & $\rightarrow$ Ho & homogen \\
& & & diteri & \\
& & & ma & \\
\hline
\end{tabular}

Oleh karena chi-squarehitung < chi-square $_{\text {tabel }}$ (chi kuadrat ${ }_{\text {hitung }}<$ chi kuadrat $_{\text {tabel}}$ ), maka Ho diterima. Artinya, data sampel tes awal kelompok eksperimen berdistribusi normal dan homogen. Untuk perhitungan uji normalitas dapat dilakukan dengan menggunakan teknik P-P Plot.

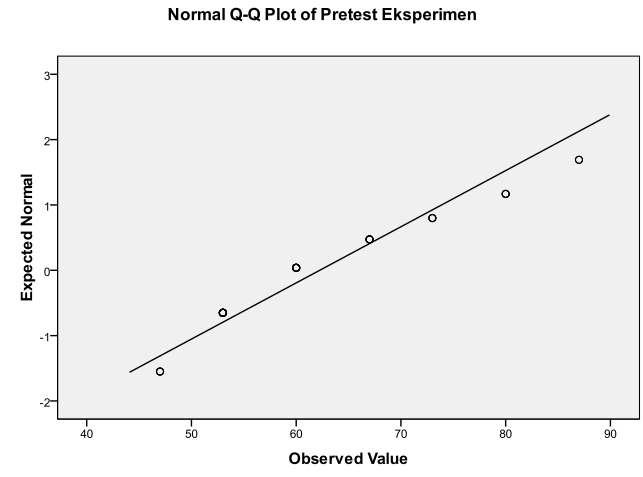

Grafik 2. P-P Plot untuk Nilai Tes Kelas Eksperimen

Grafik P-Plot di atas menunjukkan bahwa titik-titik data menyebar di sekitar garis diagonal, maka sebaran distribusi data dinyatakan normal. Dengan demikian, dapat dikatakan bahwa sampel pada tes kelompok eskperimen berdistribusi normal dan homogen.

\section{Pengujian Hipotesis}

Pengujian hipotesis dalam penelitian ini dilakukan untuk mengetahui signifikansi pengaruh model pembelajaran Learning Cycle berbasis media audio visual terhadap kemampuan menulis puisi siswa kelas $\mathrm{X}$ SMA Negeri 1 Lubai. Data yang diperoleh dianalisis dengan menggunakan uji-t pada taraf signifikansi $5 \%(\alpha=0.05)$ atau uji-t pada taraf signifikansi 95\%. Pengolahan dilakukan dengan cara menggunakan program SPSS 17. 
Tabel 9. Statistik Kelompok

\begin{tabular}{llrrrr}
\hline & Kelompok & N & Mean & $\begin{array}{c}\text { Std. } \\
\text { Deviasi }\end{array}$ & $\begin{array}{c}\text { Rata-rata } \\
\text { tingkat } \\
\text { kesalahan }\end{array}$ \\
\hline $\begin{array}{llrrrr}\text { Nilai tes } \\
\text { akhir }\end{array}$ & Eksperimen & 35 & 87 & 9.333 & 1.322 \\
\cline { 2 - 6 } & Kontrol & 36 & 71,72 & 11.982 & 1.421 \\
\hline
\end{tabular}

Pengujian tabel (9) diketahui kelompok eksperimen dengan jumlah sampel (N) 35 siswa yang memiliki rerata (mean) nilai tes sebesar 87 dengan simpang baku (Std. Deviation) sebesar 9.333 dan rata-rata tingkat kesalahan (Std. Error Mean) sebesar 11.982 sedangkan kelompok kontrol (pembanding) dengan jumlah sampel (N) 36 siswa yang memiliki rerata (mean) nilai tes sebesar 71.72 dengan simpang baku (Std. Deviation) sebesar 11.982 dan rata-rata tingkat kesalahan (Std. Error Mean) sebesar 1.421.

Tabel 10. Uji Perbandingan Sampel (Independent Sample Test)

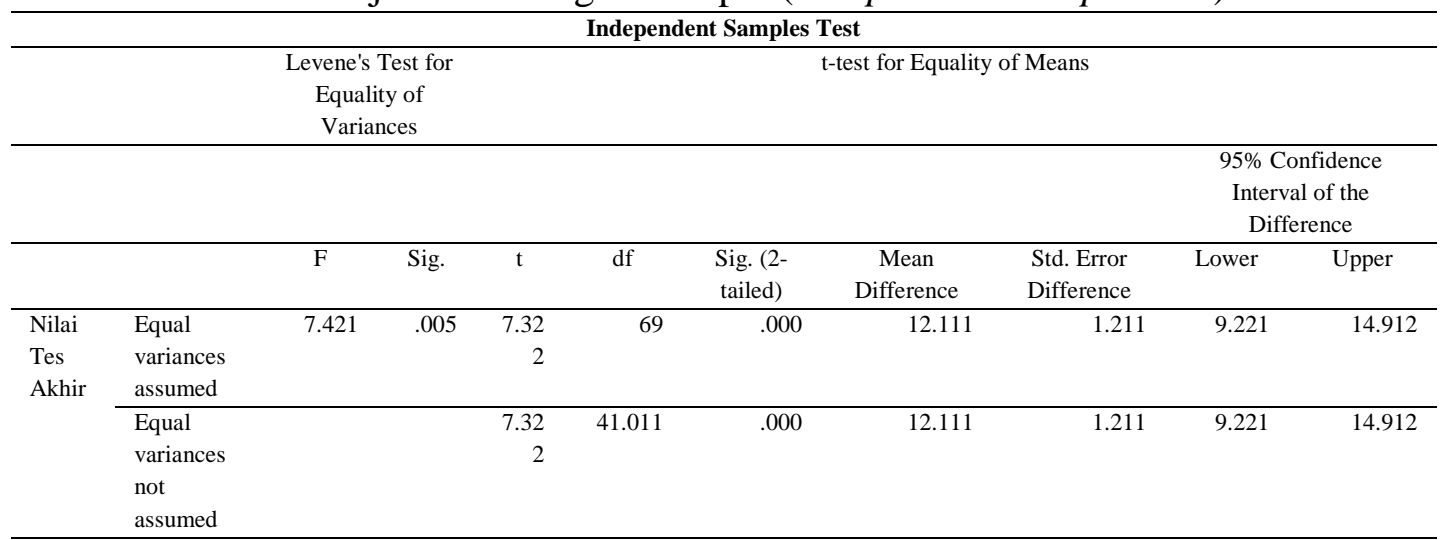

Keterangan :

Equal variance assumed =diasumsikan ada perbedaan varian

Equal varian non assumed = tidak diasumsikan ada perbedaan varian

Levene's test for equalit of variance $=$ tes levence untuk derajat varian

T-test for equality of mean = Uji-t untuk derajat kemaknaan

Sig. (2-Tailed) = kemaknaan dua sisi

Mean difference $\quad=$ rerata perbedaan

Srt. Error difference = perbedaan tingkat kesalahan

95\% confidence interval of difference $=$ interval perbedaan pada tingkat kepercayaan $95 \%$

Lower $\quad=$ nilai terendah

Upper = nilai $\mathrm{t}$

Keterangan Hasil

Tabel independen sampel tes

Nilai mean 12.111

Artinya, perbedaan rata-rata nilai akhir eksperimen dan nilai akhir kontrol adalah sebesar 12.111. Perbedaan tertinggi (upper) adalah 14.912 dan nilai perbedaan terendah (lower) adalah 9.221

Nilai t-hitung: 7.322 , tingkat signifikansi $(2$ sisi $)=0.000$

t-tabel: $(0.25 ; 69)=1.668$ 
Data di atas dapat disimpulkan, pada pengujian hipotesis dari perbandingan rata-rata kelompok eksperimen dengan rata-rata kelompok kontrol diperoleh thitung sebesar 7.322 dan tabel (df 69) sebesar 1.668. Jadi nilai $t_{\text {hitung }}(7.322)>t_{\text {tabel }}($ df 69) sebesar $1.668 \rightarrow$ Ho ditolak, artinya terdapat pengaruh model pembelajaran learning cycle berbasis media audio visual terhadap kemampuan menulis puisi siswa kelas X SMA Negeri 1 Lubai.

Dengan demikian, maka dalam penelitian ini $\mathrm{Ha}$ diterima dan $\mathrm{Ho}$ ditolak, sehingga ada pengaruh model pembelajaran learning cycle berbasis media audio visual terhadap kemapuan menulis puisi siswa kelas X SMA Negeri 1 Lubai.

Pada hasil analisis data penelitian yang telah dilakukan oleh peneliti dengan cara memberikan tes, bahwa siswa yang menggunakan pembelajaran model learning cycle berbasis media audio visual mendapatkan hasil yang lebih besar jika dibandingkan dengan hasil belajar siswa pada kelas yang menggunakan model pebelajaran biasa.

Hal ini terlihat jelas pada nilai rata-rata hasil tes. Kelas yang menggunakan model pembelajaran learning cycle berbasis media audio visual nilai rata-rata hasil tesnya adalah $\overline{X_{1}}=87$ sedangkan pada kelas yang tidak menggunakan pembelajaran model pembelajaran learning cycle berbasis media audio visual rata-rata hasil tesnya adalah $\overline{X_{2}}=71,72$ dari analisis diperoleh $t_{\text {hitung }}=7.421$ dan $t_{\text {tabel }}=1,668$ dengan $\mathrm{dk}=69$ dan $\alpha=$ $5 \%$.

Sesuai dengan kriteria pengujian hipotesis yang telah dirumuskan yaitu tolak Ho jika $t_{\text {hitung }}>t_{(1-\alpha)}$ dengan $\mathrm{dk}=$ $n_{1}+n_{2}-2$ dan peluang $(1-\alpha)$, maka nilai $t_{\text {hitung }}>t_{\text {tabel }}$ yaitu $7.322>1,668$. Yang artinya penggunaan model pembelajaran learning cycle berbasis media audio visual mempunyai pengaruh positif yang signifikan terhadap kemampuan menulis puisi.

Pengaruh positif di sini artinya nilai yang diperoleh dari analisis bernilai positif dan tidak bernilai minus, sehingga hipotesis alternatif $\left(\mathrm{H}_{\mathrm{a}}\right)$ yang diajukan diterima dan hipotesis nol $\left(\mathrm{H}_{0}\right)$ ditolak.

Dengan demikian hal ini sesuai dengan hipotesis penelitian yang telah dikemukakan bahwa ada pengaruh model pembelajaran learning cycle berbasis media audio visual terhadap kemapuan menulis puisi siswa kelas $\mathrm{X}$ SMA Negeri 1 Lubai terbukti kebenarannya.

Menurut Dalman (2016: 3), menulis merupakan proses kreatif menuangkan gagasan dalam bentuk bahasa tulis dalam tujuan, misalnya memberi tahu, menyakinkan, dan menghibur. Sedangkan puisi menurut (Hetilaniar, 2017: 2) puisi merupakan ungkapan perasaan atau curahan hati pengarang yang dituangkan ke dalam susunan kata-kata indah, padat yang 
mengandung makna yang disusun sedemikian rupa oleh pengarangnya agar pembaca dapat memahami pesan apa yang disampaikan oleh pengarangnya dalam puisi tersebut.

Menurut Armariena (2018), dalam proses pembelajaran Bahasa Indonesia khususnya penulisan puisi yang diberikan oleh tenaga pengajar menggunakan model sugesti imajinasi, model tersebut digunakan agar mahasiswa lebih aktif dalam menerima pelajaran yang disampaikan bukan hanya sekadar paham dan mampu melakukan suatu pekerjaan sesuai dengan tujuan pembelajaran yang telah ditetapkan, tetapi juga agar terbentuk sikap-sikap positif.

Menurut (Masnunah, 2018: 236), penguasaan bahasa tulis telah didasari mutlak diperlukan dalam kehidupan modern, tetapi pada kenyataan pengajarannya kurang mendapat perhatiannya.

Masnunah (2018: 236) menjelaskan bahwa proses menulis puisi yang penting adalah memahami puisi, membaca, melihat, mendengar sehingga akan terpikirkan memilih diksi yang tepat dan mengait-aitkan huruf awal dengan gagasan yang akan dikemukan.

Kata pembelajaran mengandung arti proses membuat orang melakukan proses belajar sesuai dengan rancangan. Pembelajaran adalah merupakan sarana untuk memungkinkan terjadinya proses belajar dalam arti perubahan prilaku individu melalui proses mengalami sesuatu yang diciptakan dalam rancangan proses pembelajaran (Ngalimun, 2017: 44).

Model pembelajaran dapat diartikan sebagai prosedur sistematis dalam mengorganisasikan pengalaman belajar untuk mencapai tujuan belajar, model pembelajaran bisa juga diartikan suatu pendekatan yang digunakan dalam kegiatan pembelajaran (Ngalimun, 2017: 37).

Model pembelajaran learning cycle adalah model pembelajaran yang memiliki siklus empat-tahap yang di dalamnya peserta didik atau siswa melakukan beberapa rangkaian tahap (Huda, 2019: 265).

Kata media berasal dari bahasa latin medius yang secara harfiah berarti 'tengah', 'perantara' atau 'pengantar'. Dalam bahasa Arab, media adalah perantara atau pengantar pesan dari pengirim kepada penerima pesan. Secara lebih khusus, pengertian media dalam proses belajar mengajar cenderung diartikan sebagai alat-alat grafis, foto grafis atau elektronik untuk menangkap, memproses dan menyusun kembali informasi visual atau verbal, (Arsyad, 2013: 3).

Aminuddin (2013: 134) mengemukakan puisi adalah karya sastra yang membuat kata-kata juga mewakili suatu perasaan penulis, indah dan penuh makna yang disusun dengan baik dan kalimat puitis yang terkandung dalam penggalan setiap kata-kata penuh makna serta memiiki wujud yang berbeda pula. Selanjutnya Pradopo (2010:7) menjelaskan bahwa 
suatu puisi karya sastra yang merupakan suatu rekaman dan interpretasi pengalaman manusia yang penting, yang dapat diubah dalam sebuah wujud yang sangat berkesan.

Besarnya pengaruh tersebut mengindikasikan besarnya perbedaan hasil belajar siswa antara kelas eksperimen atau yang dikenai perlakuan model pembelajaran learning cycle berbasis media audio visual dengan kelas kontrol atau yang tidak dikenai perlakuan model pembelajaran learning cycle berbasis media audio visual. Hal ini dapat disebabkan model pembelajaran learning cycle berbasis media audio visual mempunyai keunggulan antara lain: metode model pembelajaran learning cycle berbasis media audio visual dilandasi oleh teori belajar konstruktivitas yaitu pembelajaran yang dimulai dengan menyajikan permasalahan nyata serta penyelesaiannya (pemecahan masalah) dalam mendapatkan pengetahuan dan konsep-konsep dasar keilmuan sebagai konteks bagi peserta didik untuk belajar berpikir kritis, dan tampil memecahkan masalah tentunya mendukung timbulnya kerja sama di antara siswa.

Model pembelajaran learning cycle berbasis media audio visual juga mendukung terciptanya suasana kelas yang fleksibel dan berorientasi pada penyelidikan atau inkuiri oleh siswa. Dengan adanya penerapan model pembelajaran learning cycle berbasis media audio visual dapat dikatakan bahwa salah satu kunci keberhasilan dalam pelaksanaan pembelajaran yang dapat dijadikan alat guru untuk membantu siswa, agar dapat dengan mudah memahami dan menguasai materi yang diajarkan. Seiring dengan itu, hasil belajar dicapai oleh siswa akan meningkat secara optimal.

\section{SIMPULAN}

Berdasarkan uraian penulis dalam bab-bab sebelumnya dapat disimpulkan dan disarankan hal-hal sebagai berikut.

(1) Rata-rata hasil tes siswa kelompok eksperimen atau yang dikenai perlakuan model pembelajaran learning cycle berbasis media audio visual terhadap kemampuan menulis puisi lebih besar dibandingkan dengan rata-rata hasil tes siswa kelompok kontrol dengan menggunakan model pembelajaran biasa.

(2) Terdapat pengaruh model pembelajaran learning cycle berbasis media audio visual terhadap kemapuan menulis puisi siswa kelas X SMA Negeri 1 Lubai yang ditunjukkan dengan koefisien $t_{\text {hitung }}$ sebesar 57.322 atau lebih besar dari koefisien $t_{\text {tabel }}$ sebesar 1,668 .

(3) Dari hasil penelitian diperoleh tes hasil belajar siswa yang menggunakan model pembelajaran learning cycle berbasis media audio visual lebih baik hasilnya daripada tes hasil belajar 
menggunakan model pembelajaran biasa.

\section{REFERENSI}

Aminuddin. (2014). Pengantar Apresiasi Karya Sastra. Bandung: Sinar Baru Algensindo.

Arikunto, S. (2006). Prosedur Penelitian Suatu Pendekatan Praktik. Jakarta: Rineka Cipta.

Armariena, D. N. (2018). Penulisan Puisi Bertema Lokal Budaya dengan Model Sugesti Imajinasi Mahasiswa. Jurnal Parataksis: Jurnal Bahasa Sastra, 1 (1), 1-9.

Azhar, A. (2014). Media Pembelajaran. Jakarta: PT Raja Grafindo Persada.

Dalman. (2016). Keterampilan Menulis. Jakarta: Rajawali Pers.

Hetilaniar. (2017). Strategi Jumput dalam Pembelajaran Puisi. Palembang: Noer Fikri.
Huda, M. (2019). Model-Model Pengajaran Dan Pembelajaran. Yogyakarta: Pustaka Pelajar.

Masnunah. (2018). Pengaruh Model Pembelajaran Somatis Auditori Visual Intelektual (Savi) terhadap Menulis Puisi pada Siswa Kelas VIII SMP Negeri 35 Palembang. Seminar Nasional Pendidikan Universitas PGRI Palembang. Program Pascasarjana Universitas PGRI Palembang

Ngalimun. (2017). Strategi Pembelajaran. Yogyakarta: Parama Ilmu.

Pradopo, R. D. (2010). Pengkajian Puisi: Analisis Strata Norma dan Analisis Struktual dan Semiotik. Yogyakarta: Gajah Mada University Press.

Sugiyono. (2017). Metode Penelitian Kuantitatif, Kualitatif dan $R \& D$. Bandung: Alfabeta.

Sukardi. (2011). Metodologi Penelitian Pendidikan Kompetensi dan Praktiknya. Yogyakarta: Bumi Aksara. 